www.volsu.ru

DOI: http://doi.org/10.15688/nav.jvolsu.2016.1.8

UDC 930.26(470+571):641

LBC 63.48(2)-414

\title{
A NEW FINDING OF EASTERN TOREUTICS OF THE MIDDLE AGES IN THE SOUTHERN URALS
}

\author{
Svetlana L. Vorobyeva \\ National Museum of the Republic of Bashkortostan, Ufa, Russian Federation \\ Gennadiy N. Garustovich \\ Ufa Scientific Center of the Russian Academy of Sciences, Ufa, Russian Federation
}

\begin{abstract}
The authors examine one of the findings in the Southern Urals - fragment of a jug made of brass of Iranian origin. This unique item of the $12^{\text {th }}$-beginning of the $13^{\text {th }}$ centuries is decorated by embossing and inlays, complex patterns of arabesques and figures of lions (the body of the vessel is not preserved). The Basma technique on both sides of the neck of the housing relief shows a figure of sitting lions in heraldic position. At the top of the drain- spout another figure is noticeable - a reclining lion, which had been drafted, but had not been worked out the whole way. "Lateral" figures of lions surrounded the geometric sections of the bands with varied arabesque ornaments (motifs of winding vines, rows of tulips, rhythmic interlocking lines, etc.). Elements of artistic decoration of the vessel, combining the tradition of realistic plastic silhouettes of Iranian and Muslim canonical vegetable and geometrical ornaments, are typical for construction of decorative patterns in toreutics periods till the domination of the representatives of the Turkic Seljuk dynasty in Iran. Analogs of this jug show the gradation of vessels of such forms (in the form of corrugated bud) for luxury products with rich inlay (vessels of Herat and Mosul) and simplified imitation of prestigious products (Yasydepe, Merv, Nizhnehozyatovo et al.). It is an imported product of Eastern toreutics found in the medieval villages of the Bashkirs. Ornamental composition reflects good wishes to the owner of the vessel, includes the traditional Iranian (realistic) and the Muslim plant of fine trend. Similar jugs were found in different points of Iran, but experts believe that their products are traditional artisans. Finding of the Bashkortostan Republic is the imitation of prestigious products, differing with the grace and subtlety of a professional work.

Key words: Southern Urals, Middle Ages, import, Iranian toreutics, jug, Khorasan, $13^{\text {th }}$ century.
\end{abstract}

УДК 930.26(470+571):641

ББК 63.48(2)-414

\section{НОВАЯ НАХОДКА ВОСТОЧНОЙ ТОРЕВТИКИ ЭПОХИ СРЕДНЕВЕКОВЬЯ НА ЮЖНОМ УРАЛЕ}

\author{
Светлана Леонидовна Воробьёва \\ Национальный музей Республики Башкортостан, г. Уфа, Российская Федерация
}

Геннадий Николаевич Гарустович

Уфимский научный центр Российской академии наук, г. Уфа, Российская Федерация

Аннотация. В данной статье авторы акцентируют внимание читателей на очередной находке на Юж-
том Урале произведения средневековых иранских мастеров по цветному металлу. Уникальное изделие вос-
хозятово, в самом центре современной Республики Башкортостан. Найденное здесь цилиндрическое гор-
лышко вытянутых пропорций (с выделенным носиком-сливом) от изящного кувшина из латуни обработано
способом чеканки и гравировки, украшено комбинацией разнообразных резных и выпуклых орнаментов
(тулово не сохранилось). В технике басма с двух сторон на корпусе горловины рельефно показаны фигуры
сидящих львов в геральдической позе. На вершине носика-слива заметна еще одна фигура-лежащего льва (?),
которая была намечена, но так и не проработана до конца. «Боковые» фигуры львов окружали геометричес-
кие секции из полос разнообразной арабесковой орнаментики (мотивы вьющейся лозы, рядов из тюльпа- 
нов, ритмичных переплетенных линий и др.). Элементы художественного убранства сосуда, совмещающие традиции реалистических иранских пластических силуэтов и мусульманской канонической растительно-геометрической орнаментики, типичны для построения декоративных узоров в торевтике периода господства в Иране представителей тюркской династии Сельджукидов. Аналоги нижнехозятовскому кувшину показывают градацию емкостей рассматриваемых форм (с туловом в виде гофрированного бутона) на элитную продукцию с богатой инкрустацией (сосуды из Герата и Мосула) и на упрощенные подражания престижной продукции (Ясыдепе, Мерв, Нижнехозятово и др.). Все они датируются XII - началом XIII в., причем специалисты относят эти изделия к Хорасанской (Восточноиранской) школе ремесленников-медников. По мнению авторов работы, импортный сосуд попал в землю на Южном Урале, по всей видимости, в ХІІІ в., и привезен он из Средней Азии по Волжскому торговому пути в обмен на пушнину или в качестве посольского дара исламских правителей неофитам из башкир-мусульман.

Ключевые слова: Южный Урал, средневековье, импорт, иранская торевтика, кувшин, Хорасан, XIII век.

Археологические памятники начала II тысячелетия н. э. в пределах Южного Урала по разным причинам изучены еще в недостаточной мере; особенно это касается поселенческих объектов башкирского населения в лесостепной зоне Предуралья. Авторам данной статьи хотелось бы обратить внимание на уникальную находку с территории одного из таких памятников, расположенного в самом центре Республики Башкортостан (далее - РБ).

В 1997 г. при рытье могилы на кладбище дер. Нижнехозятово (Чишминского района РБ) местными жителями было найдено горлышко кувшина изящных пропорций, тщательно изготовленного из тонкой листовой латуни. В том же году уникальный предмет восточной торевтики эпохи средневековья был передан на хранение в фонды Национального музея РБ (г. Уфа; ОФ 32708).

Деревенское кладбище расположено рядом с деревней, в 0,2 км к северо-западу от русла р. Дема и в 0,1 км к северо-востоку от старичного озера Сэнныкуль. Усадьбы деревни занимают территорию надпойменной террасы, и при земляных работах на улицах, а также на огородах периодически разрушаются древние захоронения. По мнению Б.А. Коишевского, найденные здесь обрывки кольчуг и наконечники стрел относятся к XI-XII вв. [АКБ, 1976, № 725, с. 100]. Последующие раскопки Г.И. Матвеевой (1965 г.) и Г.Н. Гарустовича (1993 г.) позволили уточнить хронологию памятника, поскольку было выявлено свыше 25 раннемусульманских башкирских захоронений XIII-XIV веков. Кроме того, со слов местных жителей стало понятно, что на территории огородов попадаются не только погребальные остатки, но и поселенческие материалы (фрагменты лепной и гончарной ке- рамики, обломки костей животных, куски глиняной обмазки, части чугунных котлов и т. д.). Вероятнее всего, изделие, о котором пойдет речь далее, связано с неисследованной до сих пор поселенческой частью памятника.

Цилиндрическое горлышко латунного кувшина из дер. Нижнехозятово имело конфигурацию сильно стилизованной птичьей головы с тонкой «шеей» и вытянутым «клювом» (рис. 1). Носик-клюв крепится под углом и возвышается над вершиной «головы» (вертикального горлышка сосуда). Высота полой цилиндрической горловины (без носика) 11,7 см, с носиком - 15,5 см. Ранее предмет крепился втульчатым способом к раздутому корпусу кувшина (к сожалению, он утрачен). Диаметр верхней части горлышка - 5 см (внутренний) и 5,8 см (внешний), нижней части - 4,2 см. Размеры носика: 6,2 × 3 см (рис. 1,a-8). Наружный край горловины оформлен накладной полосой, загнутой в виде бордюрного бортика (рис. 1,$6 ; 2,2)$.

Крепежная цилиндрическая втулка методом ковки согнута из листовой латуни (толщиной до 0,1 см); основание этой подставки выгнуто наружу (заметен соединительный шов пластины). Верхняя часть втулки (диаметр 4,9 см) немного сужается (на 0,3 см) и приобретает выпуклую форму (внутренний диаметр нижней части 5,2 см, внешний 6 см). В нижней части края подставки загнуты; поверхность втулки орнамента не имела (рис. $1, a, ж)$.

Оформление полой трубки горловины производилось способом металлопластического моделирования, с использованием методов механической сборки и «холодной сварки». По всей видимости, объемные фигуры на наружной поверхности сделаны в технике басма ${ }^{1}$, 
хотя вмятин от молотков не видно ни на лицевой, ни на оборотной стороне. Кончик слива и его вершина закрыты раскованной пластиной, на которую нанесено выпуклое изображение (льва?). О том, что пластина раскована, свидетельствуют разная толщина металла и слоистая структура по ее краям [Минасян, 2014, c. 249-250]. На кончике ребристого носика имеются четыре вырубленных сквозных отверстия прямоугольной формы (рис. 1,2; 2,б). Пластина крепится к носику (как бы надета на него), неровные края загнуты. Первоначально кувшин имел ручку, сейчас в месте ее крепления заметно неровное отверстие.

Вся наружная поверхность кувшина подверглась чеканке с последующей тщательной полировкой, от которой сохранились механические следы. Орнамент на горловине нанесен методом гравировки, о чем свидетельствуют поперечные и зубчатые риски на крутых поворотах внутри канавок. Пропорции изделия и композиция изображений были предварительно размечены заостренным предметом (следы от подобных черточек сохранились рядом с канавками). В целом, горлышко кувшина было достаточно тщательно изготовлено профессиональным мастером-медником.

Несмотря на посредственную сохранность нижнехозятовского предмета, на поверхности горлышка и носика хорошо заметен резной и выпуклый орнамент. Нижняя сужающаяся часть горловины, которая крепится к подставке, украшена по тулову параллельными вертикальными гравированными линиями, над которыми нанесены две горизонтальные полосы и двудольные листы.

На цилиндре горловины методом металлопластики и чеканки с двух сторон от носика нанесен орнамент, в центре которого помещены фигуры спокойно сидящих львов (рис. $1, \partial ; 2,8$ ). Поза зверей типично геральдическая - в профиль, с прорисовкой одного глаза и заостренного кончика уха, а также гривы (она показана тремя завитками кверху). Задние лапы поджаты, зверь опирается на вытянутые передние конечности; хвост опущен и помещен под задними лапами. Фигуры прорисованы достаточно четко, но без выраженного реализма и при отсутствии визуальной перспективы. Поэтому мы считаем, что перед нами лишь идеальный образ «царя зверей», не выходящий за пределы геральдической стилизации.

Лев по всей Евразии считался отражением символики силы, мужества и великодушия. В Иране крупные кошачьи в средневековье олицетворяли верховную власть, доблесть и отвагу, постепенно сдвигаясь в сторону эмблемных реалий астрологического (солярного и лунного) символизма, где мощь и великолепие, блеск и стойкость уравновешивались свирепостью и бранной (звериной) жестокостью. Появление на желтом фоне бронзовых изделий фигурок львов - носителей царственности и света (в персидской традиции), дарующих заступничество от зла (в общемусульманской мифологии), вовсе не случайно: это декоративное благопожелание человеку. Отметим, что в эпоху Сельджукидов иранский образ «благородного» льва подпитывался почитанием силы и отваги этого животного у тюркских завоевателей. У элиты турок-сельджуков было принято добавлять к имени титульную приставку «Арслан» («лев»), и в искусстве этого времени грозному хищнику уделялось достаточно пристальное внимание [Райс, 2004, с. 179]. Персональное внимание ретроспекции «львиных» образов в искусстве Ирана уделил в своем докладе на III Международном конгрессе иранского искусства и археологии А.А. Ромаскевич [Ромаскевич, 1939, с. 209-215].

На раскованной пластине, закрывающей носик и верх слива сосуда методом формовки по матрице и чеканки нанесена выпуклая фигура неправильной овальной (восьмерковидной) формы - возможно, лежащее стилизованное животное, и скорее всего - лев. Точнее сказать не представляется возможным, так как изображение уж слишком схематичное (рис. $1, e ; 2, a$ ). Фигуры львов по обеим сторонам горловины окантованы вертикальными П-образными узорными рамами, соединенными в основании горизонтальной линией из тюльпанов в ряд (после чего рамки приобрели прямоугольную форму). В каждой штанге П-образной фигуры методом гравировки выведены ленты переплетенных полос и ритмичный ряд растительных побегов (рис. 1,d). Со стороны носика перекрещиваются волнистые линии (орнамент «сплетенная веревка»), сверху - параллельные широкие полосы (мо- 
тив «каната»), а со стороны рукояти кувшина нанесен сложный растительный орнамент мотив тюльпана (рис. 1,d).

Носик-слив имеет четыре грани, каждая из которых орнаментирована растительной плетенкой (рис. 1,д; 2,2). На крайних к тулову гранях нанесена рамка из двух параллельных линий, внутри которых изображены двудольные листы и тюльпаны. Другие две грани, расположенные по центру носика, орнаментированы перекрещивающимися волнистыми полосами с однодольным листом (орнамент «сплетенная веревка»). Растительные стилизации были типичны для изобразительного искусства эпохи Сельджукидов; в частности, к таким орнаментам относятся мотивы тюльпана или лотоса, виноградной лозы, которые, по мнению Т.Т. Райс, перешли к ремесленникам Сельджукидов из прежней центральноазиатской традиции. Изображение же плоского листа, состоящего из двух долей, которые имеются на сосуде из дер. Нижнехозятово, можно относить к мотивам сельджукского времени; иногда между ними помещался третий элемент. В любом случае, одна из боковых долей неизменно бывает вытянутой и слегка заостренной [Райс, 2004, с. 173-176]. Дата сосуда из дер. Нижнехозятово - XIIXIII вв., а его попадание в землю, скорее всего, относится к XIII веку.

Специалисты по стилистике и орнаментальным мотивам восточной торевтики подчеркивают, что в период правления представителей династии Сельджукидов художественная обработка цветного металла в Иране достигает высокого уровня. В XI-XIII вв. появляются новые технологические черты: развиваются способы инкрустации бронзы цветными металлами: серебром и красной медью. Зародившись в VIII в., этот прием часто сочетался с гравировкой и рельефом и получил широкое распространение на Ближнем и Среднем Востоке. Инкрустация выделяла элементы узора, оживляла и обогащала фактуру изделия цветом [Сазонова, 2002]. На место прежних фигур людей, зверей и знаков зодиака с начала II тысячелетия все чаще «заступают» отвлеченные растительные орнаментальные ленты (арабески), «ковровые» цветочные композиции, признанные допустимыми в строгих мусульманских канонах. Время под- твердило справедливость слов А.Ю. Якубовского, высказанных им на заседании III Международного конгресса по иранскому искусству и археологии (Ленинград, 1935 г.): «Хорошо известно, что в Средней Азии господствовал один из ортодоксальных мусульманских толков - ханифитский. Последний требовал в изобразительном искусстве строго обобщенного стиля, который сводился всегда к тому типу рисунка, где сильно стилизованные растительные мотивы, введенные в геометрический орнамент, вместе с надписями составляли строгие орнаментальные композиции, и где почти совсем исключалось изображение животных и людей. В самом Иране, где ислам всегда имел ряд еретических течений, развивалось более свободное художественное творчество с сильно развитым изобразительным элементом» [Деннике, 1935, с. 162]. Лишь со временем ранние описательные темы в искусстве и реалистические изображения переходят в разряд ритмического узора. При этом причины распространения изделий из меди и ее сплавов аргументируются специалистами не только в плане неизбежных последствий серебряного кризиса на Востоке, но и в связи с ростом потребностей среднего класса общества, а также с призывами мусульманских богословов к сдержанности и аскетизму в быту. На горлышке нижнехозятовского кувшина мы как раз видим совмещение древних иранских и мусульманских традиций: львов, вписанных в геометрические секции разнообразной арабесковой орнаментики.

В целом, растительный орнамент (арабеска), по мнению Т.Ю. Николаевой, также полон скрытой символики. Он отражал разнообразие окружающей вселенной, «прославление и любование миром, созданным Аллахом для человека... Изображение красоты и умиротворенности переплетающихся цветов и трав, птиц вызывает в памяти коранические картинки райских садов... Он создает ощущение бесконечного движения, полного повторений, разнообразия и подвижности, и как бы передает идею беспрерывности, бесконечности и многообразия, которые и составляют важный аспект представления о Боге. Такой художественный намек или напоминание о божественной сути является характерной чертой всех типов мусульманского орнамента. 
Поэтому для мусульманского искусства становится обязательным заполнение всякого пустого пространства» [Николаева, 2011, с. 240]. В создаваемой гармонии преобладает смешанная структура арабеска посредством переплетения различных геометрических фигур и слияния растительных узоров, подчиненных внутреннему ритму. Искусствоведы предпочитают видеть в этом слиянии различных ростков и листьев замысловатое пересечение жизненной линии человека и его духовности. Можно говорить, что на нижнехозятовском кувшине прослеживается эстетическое совмещение в художественном убранстве мотивов различной природы: пластических силуэтов и растительно-геометрической орнаментики при явном возрастании декоративных тенденций в динамике узоропостроения.

Аналоги. Привлечение аналогов необходимо по следующим причинам: а) они дают нам возможность представить полную форму кувшина, горловина которого обнаружена в Башкортостане; б) территориальное распространения схожих находок позволяет представить направление международных купеческих магистралей, номенклатуру и ассортимент средневекового товарообмена; в) в детализации нуждаются вопросы датировки и место создания подобной престижной ремесленной продукции.

Начнем с латунного сосуда, изготовленного в Герате (Хорасан) в промежуток от 1180 до 1210 г. [Руденко, 2001, с. 116, рис. 14]. Кувшин инкрустирован серебром и черным составом; высота сосуда 40 см, диаметр 19,1 см $(\text { рис. } 3)^{2}$. Сравнение емкостей из Герата и Нижнехозятово показывает, что они по пропорциям горлышка и носика идентичны, точно так же, как и по стилистике орнаментации. Правда, на кувшине из Башкортостана заметно несколько специфических деталей: на носике животное изображено более стилизованно, фигуры львов на горловине также выглядят схематичнее; отсутствует обилие растительных орнаментов в нижней части горлышка. Все это говорит о том, что рассматриваемый нами сосуд является подражанием изделию из Герата. Если они и были сделаны в разных местах, то мастер должен был видеть сосуд, на котором подробно проработаны детали изображений (такой, как на изделии из Герата). Таким образом, нижне- хозятовский кувшин первоначально, по всей видимости, имел гофрированный корпус кубкообразной (в виде бутона) формы, с невысоким кольцевым поддоном и ручкой арочной формы (верхний ее конец был прикреплен к горлу, нижний - к тулову). Элитный кувшин из Герата сделан более профессионально и тщательно, украшен и инкрустирован он аккуратнее и изысканнее (рис. 3).

Еще более сложный и детализированный декор с насечкой виден на бронзовом кувшине из Мосула (Ирак, около 1200 г.). Отметим, что у этого сосуда на носике заметна вполне реалистичная фигура лежащего льва, а не безликая стилизация, как в Нижнехозятово.

Устойчивость формы кувшина с гофрированным туловом подтверждается на примере еще одного близкого аналога - из г. Нахчывана (Азербайджан), отнесенного Т. Достиевым к XII-XIII вв. [ХКЦАА, 2012, с. 273, рис. 2]. В качестве аналога данного сосуда назван предмет конца XII в. из города Исфахана (со ссылкой на: $\mathrm{SPA}^{3}, 1965$, vol. 12). Автор отмечает, что в эпоху Сельджукидов Хорасанская школа металлообработки становится одним из ведущих художественных центров мусульманской Центральной Азии, влияние которого прослеживается на ремесленной продукции от Ширвана до Сиистана; в ней отражается дворцовая роскошь и при этом проявляется своеобразная альтернатива нарастающему исламскому ригоризму [ХКЦАА, 2012, с. 269].

Отметим, что поиск новых форм в производстве посуды был процессом постепенным и основывался на технологических умениях предыдущих веков. Именно в этой плоскости (но не в качестве прямого аналога) мы рассматриваем найденное горлышко литого (выделено нами. - C. В., Г. Г.) кувшина из Ясыдепе (Туркменистан) XII-XIII веков. Здесь конфигурация деталей сосуда несколько иная, но построение стилистики формы и орнаментики схожи [ХКЦАА, 2012, с. 137, 208, рис. XIII, $a$; XIV]. Находки кованных медныХ и бронзовых сосудов XII-XIII вв. из Мерва [ХКЦАА, 2012, с. 206, рис. VIII, $a-8$ ] или из того же Ясыдепе [ХКЦАА, 2012, с. 207, рис. X, XI] показывают направления в поиске новых форм и технологий мусульманской торевтики Восточного Ирана. Одной из тенденций этого процесса стало широкое распрост- 
ранение кованых фигуративных емкостей с «птицеголовыми» вертикальными горлышками и корпусом в виде груши или граненого цветочного бутона.

По рассказу Бируни, еще в начале VIII в. омейядский наместник ал-Хаджжадж ${ }^{4}$ пытался запретить использование сосудов из золота и серебра в халифате. Персидские мастера вынуждены были продолжить работу с цветным металлом, задействуя вначале сплав серебра и меди, а затем - меди и свинца [Бируни, 1963, с. 246; Даркевич, 1976, c. 132]. Серебряный кризис начала II тысячелетия на Востоке еще больше способствовал популярности изделий из бронзовых сплавов с применением инкрустации. На смену естественной ценности благородных металлов и парадно-эпических изображений «сасанидского серебра» приходила тщательность обработки и ковровая тонкость секторной орнамен- тики на меди и бронзе. Около середины XII в. мастерские бронзовой утвари с насечкой возникают в Хорасане. «Из Герата вывозятся в другие местности всякого рода диковинки, например - медные сосуды, инкрустированные серебром» (ал-Казвини, географ XIII в.) (цит. по: [Даркевич, 1976, с. 161]). Именно из Хорасана (в широком плане - с территории Восточного Ирана) через Среднюю Азию изделия мусульманских торевтов продолжали попадать на Среднюю Волгу и Урал. Новый подъем волжской торговли со Средней Азией относится ко второй половине XII - первой трети XIII в., причем на смену парадным чашам приходят изделия художественно-бытового назначения. Но объем этой торговли так и не достиг прежнего уровня. На примере рассмотренного кувшина из дер. Нижнехозятово в очередной раз подтверждаются выводы специалистов. 


\section{ИЛЛЮСТРАЦИИ}

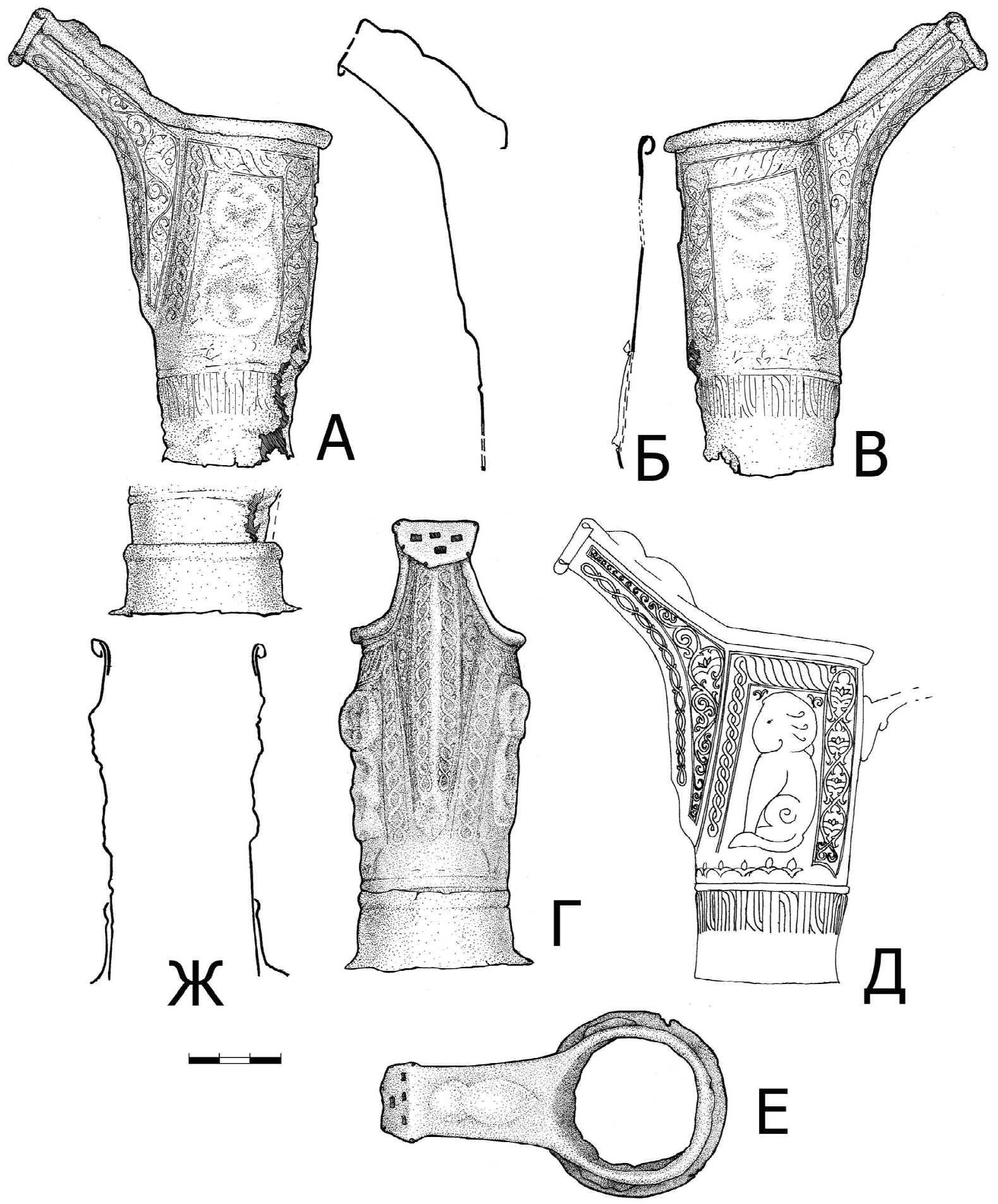

Рис. 1. Горлышко кувшина с выделенным носиком-сливом из дер. Нижнехозятово Чишминского района Республики Башкортостан. Латунь ( $a-ж-$ вид и профили горловины сосуда). Рисунки У.О. Коршуновой 

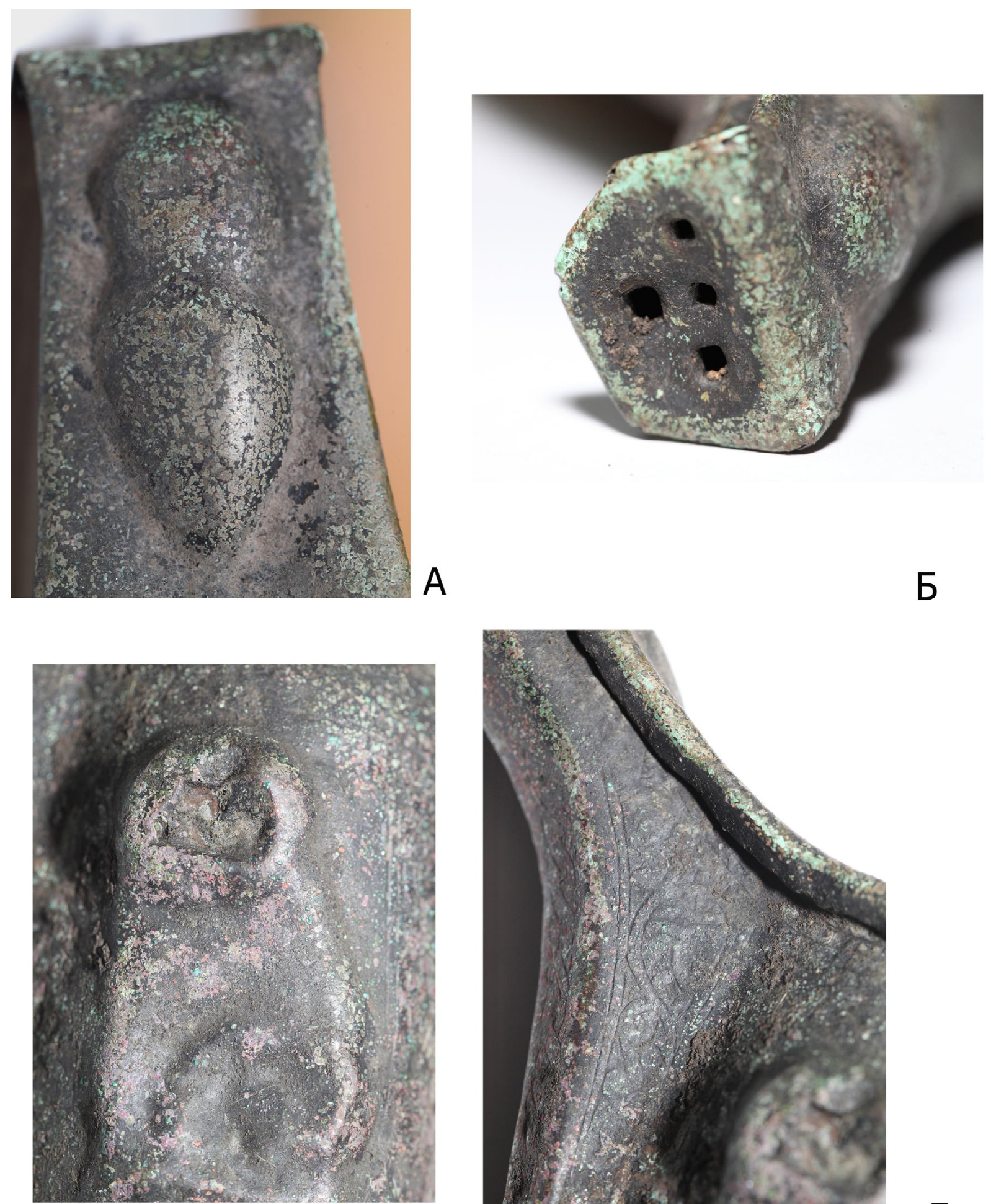

B

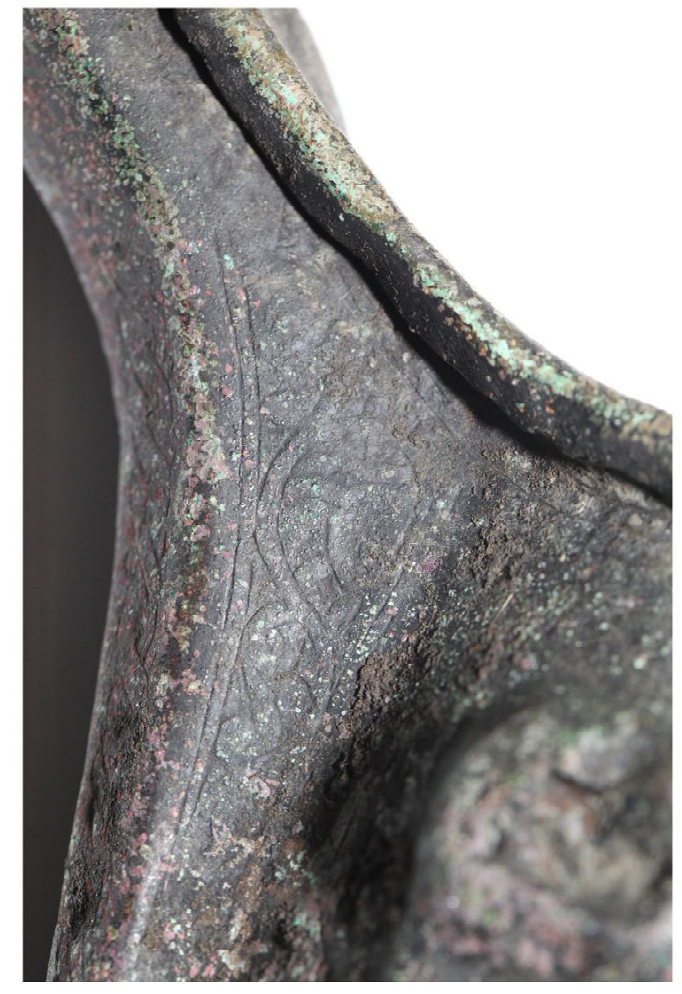

Б

Рис. 2. Макросъемка отдельных частей латунного сосуда из дер. Нижнехозятово Республики Башкортостан (съемка П. Ю. Грабаря): $A$ - верхняя часть носика; $D$ - вид носика-слива; $B$ - корпус с изображением льва; $\Gamma$ - вид бортика на устье и растительного орнамента на носике кувшина 


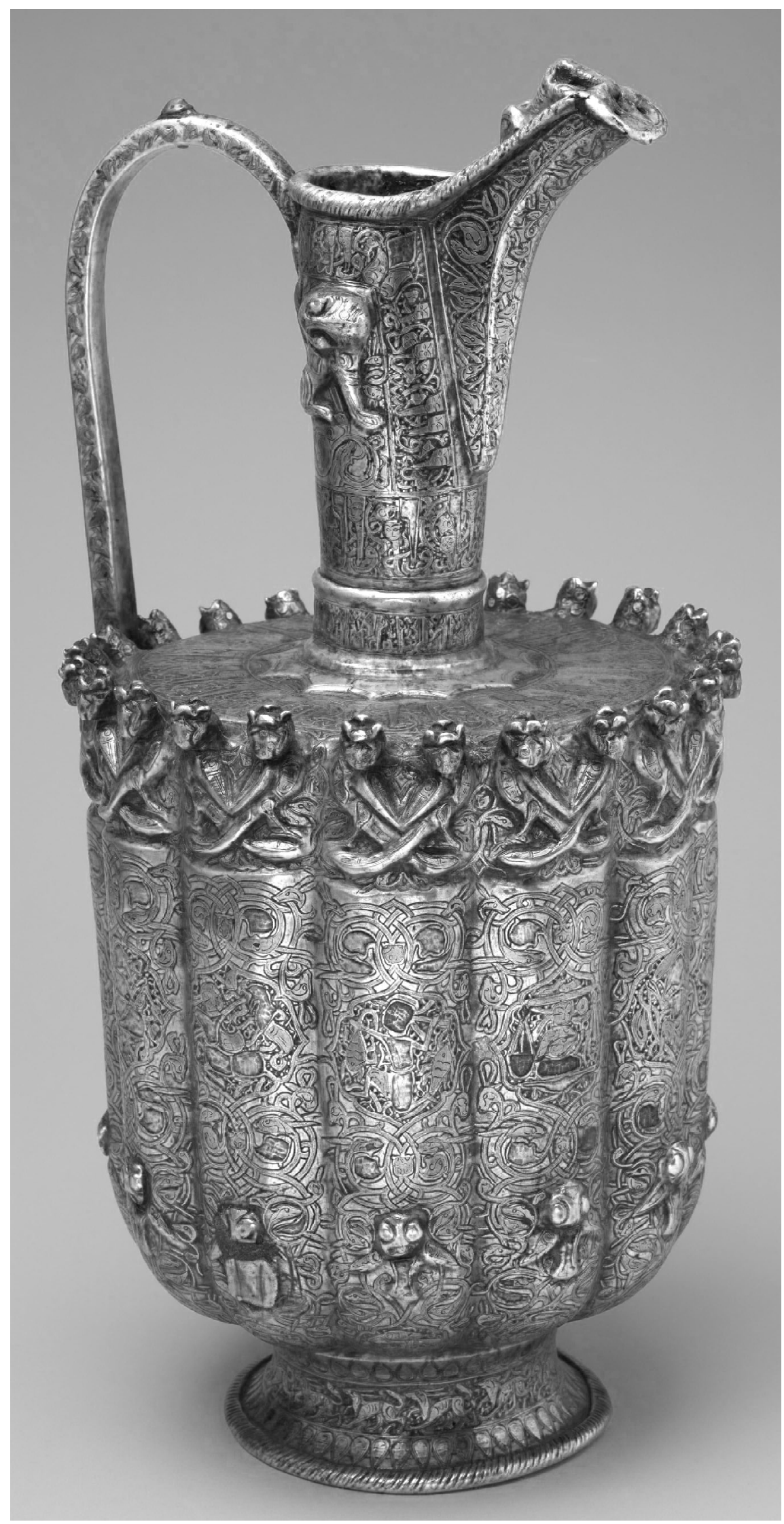

Рис. 3. Кувшин для воды. Латунь, чеканка, инкрустация серебром и черным металлом. Герат (Хорасан), 1180-1210 гг. [Руденко, 2011, с. 116, рис. 14] 


\section{ПРИМЕЧАНИЯ}

${ }^{1}$ Басма - техника выдавливания рельефов в листовом металле на литых металлических или деревянных матрицах [Минасян, 2014, с. 226].

${ }^{2}$ Хранится в Британском музее (Лондон).

${ }^{3}$ SPA - A survey of Persian Art.

${ }^{4}$ Аль-Хаджжадж («Костолом») ибн Юсуф ас-Сакафи (661-714) - арабский полководец и наместник Ирака.

\section{СПИСОК ЛИТЕРАТУРЫ}

Археологическая карта Башкирии (АКБ) (1976) / отв. ред. О. Н. Бадер. М. : Наука. 253 с.

Бируни Абу-р-Райхан Мухаммед ибн Ахмед (1963). Собрание сведений для познания драгоценностей (Минералогия) / пер. А. М. Беленицкого. М. : Изд-во АН СССР. 521 с.

Даркевич В. П. (1976). Художественный металл Востока. М. : Наука. 199 с.

Деннике Б. П. (1935). III Международный конгресс иранского искусства и археологии // Историкмарксист. М. № 10 (050). С. 160-163.

Минасян Р. С. (2014). Металлообработка в древности и Средневековье. СПб. : Изд-во ГЭ. 472 с.

Николаева Т. Ю. (2011). Трансформация принципов изображения живых существ в исламском искусстве Ирана (на примере керамики) // Вестник Московского государственного университета культуры и искусств. М. № 2 (40). Март - апрель. С. 238-242.

Райс Т. Т. (2004). Сельджуки. Кочевники - завоеватели Малой Азии / пер. с англ. О. И. Миловой. М. : Центрполиграф. 238 с.

Ромаскевич А. А. (1939). Изваяния и изображения львов в Иране // Иранское искусство и археология : III Международный конгресс по иранскому искусству и археологии, Ленинград, сентябрь 1935 г. / И. А. Орбели (ред.). М. ; Л. : Изд-во АН СССР. С. 209-215.

Руденко К. А. (2001). Бронзовые чаши с серебряной инкрустацией из собрания Национального музея РТ (к вопросу о булгарской торевтике эпохи Золотой Орды) // Татарская археология. Казань : Институт истории Академии наук Татарстана. № 1-2 (8-9). С. 91-117.

Сазонова Н. В. (2002). Искусство Ирана // Архив электронного журнала «Суфий». Декабрь, 21. URL: https://oldsufiwebzine.wordpress.com (дата обращения: 01.11.2016).
Художественная культура Центральной Азии и Азербайджана IX-XV веков (ХКЦАА) (2012) / науч. ред. К. Байпаков, Ш. Пидаев, А. Хакимов. Самарканд ; Ташкент : МИЦАИ. Т. III. Торевтика. 297 с.

\section{REFERENCES}

Archaeological map of Bashkiria (1976). Moscow, Nauka Publ. 253 p. (in Russian).

Biruni Abu-r-Rajhan Muhammed ibn Ahmed (1963). Meeting details for the knowledge of jewelry (Mineralogy). Transl. by A.M. Belenitsky. Moscow, Izd-vo Academy of Sciences of the USSR. 521 p. (in Russian).

Darkevich V.P. (1976). Art metal of the East. Moscow, Nauka Publ. 199 p. (in Russian).

Dennike B.P. (1935). Third international Congress of Iranian art and archaeology. Historian-Marxist. Moscow, no. 10 (050), pp. 160-163. (in Russian).

Minasyan R.S. (2014). Metalworking in antiquity and the middle Ages. Saint Petersburg, Izd-vo SE. 472 p. (in Russian).

Nikolaeva T.Yu. (2011). Transformation of principles of living creatures images in Islamic art of Iran (on the example of ceramics). Bulletin of Moskow State university of culture and arts, March-April, no. 2 (40), pp. 238-242. (in Russian).

Rays T.T. (2004). The Seljuqs. Nomadic conquerors of Asia Minor. Transl. by O. I. Milova. Moscow, Tsentrpoligraf Publ. 238 p. (in Russian).

Romaskevich A.A. (1939). Sculptures and images of lions in Iran. Iranian art and archaeology: third international Congress on Iranian art and archaeology. Moscow; Leningrad, Akademiya nauk SSSR Publ., pp. 209-215. (in Russian).

Rudenko K.A. (2001). Bronze bowls with silver inlay from the collection of the National Museum of Tatarstan (on Bulgarian toreutics epoch of the Golden Horde). Tatar archaeology. Kazan, Institut istorii Akademii nauk Tatarstana, no. 1-2 (8-9), pp. 91-117. (in Russian).

Sazonova N.V. (2002). The Art of Iran. Archive of the electronic journal "Sufi", December 21. Available at: https://oldsufiwebzine.wordpress. com (accessed November 1, 2016). (in Russian).

The artistic culture of Central Asia and Azerbaijan in $9^{\text {th }}-15^{\text {th }}$ centuries (2012). Vol. III. The toreutics. Samarkand, Tashkent, MITSAI. 297 p. (in Russian). 


\section{Information about the Authors}

Svetlana L. Vorobyeva, Candidate of Sciences (History), Researcher, Department of Funds, National Museum of the Republic of Bashkortostan, Sovetskaya St., 14, 450008 Ufa, Russian Federation, sveta_legion@mail.ru.

Gennadiy N. Garustovich, Candidate of Sciences (History), Senior Researcher, Department of Archaeological Research, Institute of History, Language and Literature, Ufa Scientific Center of the Russian Academy of Sciences, Prosp. Oktyabrya, 71, 450054 Ufa, Russian Federation, garustovich03@mail.ru.

\section{Информация об авторах}

Светлана Леонидовна Воробьёва, кандидат исторических наук, научный сотрудник отдела фондов Национального музея Республики Башкортостан, ул. Советская, 14, 450008 г. Уфа, Российская Федерация, sveta_legion@mail.ru.

Геннадий Николаевич Гарустович, кандидат исторических наук, старший научный сотрудник отдела археологических исследований Института истории, языка и литературы Уфимского научного центра Российской Академии наук, просп. Октября, 71, комн. 402, 450054 г. Уфа, Российская Федерация, garustovich03@mail.ru.

Citation. Vorobyeva S.L., Garustovich G.N. (2016). A New Finding of Eastern Toreutics of the Middle Ages in the Southern Urals. The Lower Volga Arhaeological Bulletin, vol. 15, no. 1, pp. 126-136. (in Russian). 